\title{
Selecting Antagonistic Yeast for Postharvest Biocontrol of Colletotrichum gloeosporioides in Papaya Fruit and Possible Mechanisms Involved
}

\author{
Hamizah Hassan ${ }^{1}$, Mahmud Tengku Muda Mohamed ${ }^{1}$, Siti Fairuz Yusoff ${ }^{2} \mathbb{D}$, Erneeza Mohd Hata ${ }^{3} \mathbb{D}$ \\ and Nor Elliza Tajidin $4, * \mathbb{D}$
}

1 Department of Crop Science, Faculty of Agriculture, Universiti Putra Malaysia, Serdang 43400, Selangor, Malaysia; misz_zah@yahoo.com (H.H.); mtmm59@gmail.com (M.T.M.M.)

2 Agricultural Science Department, Faculty of Technical and Vocational, Universiti Pendidikan Sultan Idris, Tanjong Malim 35900, Perak, Malaysia; yuezyusoff@gmail.com

3 Department of Plant Protection, Faculty of Agriculture, Universiti Putra Malaysia, Serdang 43400, Selangor, Malaysia; erneeza@upm.edu.my

4 Faculty of Sustainable Agriculture, UMS Sandakan Campus, Sandakan 90000, Sabah, Malaysia

* Correspondence: ellizatajidin@ums.edu.my; Tel.: +60-89634-000 (ext. 310000)

check for updates

Citation: Hassan, H.; Mohamed, M.T.M.; Yusoff, S.F.; Hata, E.M.; Tajidin, N.E. Selecting Antagonistic Yeast for Postharvest Biocontrol of Colletotrichum gloeosporioides in Papaya Fruit and Possible Mechanisms Involved. Agronomy 2021, 11, 760. https://doi.org/ 10.3390/agronomy11040760

Academic Editor: Mukesh Dubey

Received: 28 February 2021

Accepted: 24 March 2021

Published: 13 April 2021

Publisher's Note: MDPI stays neutral with regard to jurisdictional claims in published maps and institutional affiliations.

Copyright: (c) 2021 by the authors. Licensee MDPI, Basel, Switzerland. This article is an open access article distributed under the terms and conditions of the Creative Commons Attribution (CC BY) license (https:/ / creativecommons.org/licenses/by/ $4.0 /)$.
Abstract: Colletotrichum gloeosporioides causes anthracnose disease in papaya fruit resulting in tremendous economic loss due to its latent infection. This study aimed to evaluate the biocontrol activity of antagonistic yeasts against $C$. gloeosporioides in papaya and determine the possible mechanism involved. One hundred and ten yeast strains were isolated from different parts of the papaya plant. Among them, only five strains, namely F001, F006, L003, FL013 and LP010, showed more than 55\% radial growth inhibition of $C$. gloeosporioides. These five potent yeast strains were further evaluated in vitro and in vivo. The results indicated that strain F001 had the strongest biocontrol activity based on spore germination and fungal growth inhibition. In Vivo, the strain F001 caused $66.7 \%$ and $25 \%$ reductions in disease incidence and severity, respectively. Based on molecular identification, the strain F001 was confirmed as Trichosporon asahii. Despite there was no significant induction of defense enzyme activities found on the treated fruits, SEM observation showed direct attachment of T. asahii with the fungal hyphae and interfere in their establishment to the fruit surface. Based on these findings, the antagonistic yeast T. asahii strain F001 may be used as a potential natural biological control agent against anthracnose disease in papaya fruit.

Keywords: biocontrol; Colletotrichum gloeosporioides; anthracnose; papaya; Trichosporon asahii

\section{Introduction}

Anthracnose in papaya fruit is a devastating postharvest disease caused by Colletotrichum gloeosporioides where losses can be up to $62 \%$, with disease incidence ranging from $90-98 \%$ in Malaysia [1]. The fungus infection generally starts during the flowering stage and remains dormant until postharvest when it becomes favorable for colonization on the fruit tissue. Even though initial infection always occurs before harvest, symptoms typically become visible after harvest, as fungal development continues due to suitable storage conditions. Postharvest infections may occur due to inoculum availability in the processing environment, and situation becomes worse when the fruit is subjected to considerable amount of wounding after harvest [2]. Synthetic fungicides are commonly used to protect perishable fruit and vegetable from postharvest fungal diseases due to their efficacy and convenience $[3,4]$. However, prolonged use of registered chemicals fungicides result in declination in efficacy because of increasing pathogen-resistance [5,6].

Many efforts have been made to control postharvest diseases using safer alternatives [7]. The manipulation of naturally occurring antagonistic organisms in controlling 
postharvest diseases such as anthracnose disease has attracted the interest of many researchers [8]. Yeasts are one of the antagonistic organisms most reported as postharvest biocontrol agents and widely developed into registered products [9]. According to previous reports, natural yeasts are potent as biological control agents due to their strong antagonistic activities against pathogen diseases $[9,10]$. Yeast possesses some unique features, including production of extracellular polysaccharides, which promote their viability and limit the pathogens' propagules growth [11-13]. Yeast only requires simple nutrition for propagation, has flexibility in colony establishment even on dried-surfaces, and high tolerance to chemical treatments $[14,15]$. Furthermore, yeasts do not produce any allergenic spores, mycotoxins and antibiotic metabolites like other antagonist fungi and bacteria [16]. Thus, they leave no harmful residue for consumers [17].

In previous studies, it was shown that the origin of the antagonist microbe may affect the efficacy of its biocontrol activities since it involves the agent's adaptation and stability under different environments [18]. Thus, native yeast isolated from specific host plants is the most preferred to obtain reliable antagonist yeast agents. To date, there has been no reports on successful biocontrol yeast agents against $C$. gloeosporioides that causes anthracnose disease in papaya fruit $\mathrm{cv}$. Solo planted in the tropical region. Therefore, this study was conducted to: (a) isolate potential antagonist yeasts from papaya plants; (b) evaluate their in vitro and in vivo antagonist activities against C. gloeosporioides in papaya; (c) identify antagonist yeast by molecular identification; and (d) determine the possible yeast mechanisms of action, including induction of defense enzyme activities and attachment on C. gloeosporioides, in controlling anthracnose disease in papaya fruit.

\section{Materials and Methods}

\subsection{Isolation of Antagonistic Yeast}

Antagonistic yeasts were randomly isolated from the leaves, petioles, and fruit surfaces of papaya plants grown in Lanchang, Pahang (geographical coordinates: $3^{\circ} 24^{\prime} 0^{\prime \prime} \mathrm{N}$, $103^{\circ} 26^{\prime} 0^{\prime \prime} \mathrm{E}$, Malaysia). Tissue samples were cut into $6 \mathrm{~mm}$ in diameter using a sterile cork borer. Ten pieces of tissues from each sample were then soaked in test tubes containing $10 \mathrm{~mL}$ of sterile distilled water. The tubes were shaken on a shaker for $5 \mathrm{~min}$ and the mixtures serially diluted to reduce the cell concentration. Subsequently $0.1 \mathrm{~mL}$ of each dilution was plated on nutrient yeast dextrose agar (NYDA) medium using a sterile glass spreader. All the cultured plates were then incubated at $28 \pm 2{ }^{\circ} \mathrm{C}$ for $48 \mathrm{~h}$. The isolated yeasts were re-cultured on new NYDA media until pure cultures were obtained. Colonies of yeasts were chosen based on different morphological distinctions.

\subsection{Screening of Antagonist Yeast}

\subsubsection{Dual Culture Assay}

Preliminary in vitro screening was conducted for all of the isolated yeasts to evaluate their antagonistic capabilities against $C$. gloeosporioides according to the method described by Hasan [15], with minor modifications. The C. gloeosporioides used for the experiment was sourced from the Plant Pathology Laboratory, Universiti Putra Malaysia. For antagonistic capability assessment, the yeast isolates were cultured together with the pathogen on potato dextrose agar (PDA) medium. A $6 \mathrm{~mm}$ mycelial plug was taken from a seven-day-old C. gloeosporioides culture and placed at the center of the plate. Two-day-old yeast culture was then streaked on the same media at $1.5 \mathrm{~cm}$ from the plate edge. Fungus placed on a culture plate without the yeast served as the control. The plates were then incubated at room temperature $\left(28 \pm 2{ }^{\circ} \mathrm{C}\right)$ for seven days. Percent inhibition of radial growth (PIRG) was recorded based on the following formula [16]:

$$
P I R G=\frac{\mathrm{R} 1-\mathrm{R} 2}{\mathrm{R} 1} \times 100
$$

where, R1 = Radial growth of C. gloeosporioides in the control plate; and R2 = Radial growth of $C$. gloeosporioides cultivated with potential antagonistic yeast. 
Only isolates with PIRG $>55 \%$ were selected to proceed with the next experiment. This study was done in triplicates for each treatment.

\subsubsection{Agar Well Test}

Potential yeast strains with PIRG more than $55 \%$ were selected for further testing using the agar well test method described by Chanchaichaovivat et al. [17] with some modifications. A $0.02 \mathrm{~mL}$ yeast cell suspension $\left(5 \times 10^{6}\right.$ cells $\left.\mathrm{mL}^{-1}\right)$ was placed into a well at the middle of PDA mixed with $15 \%$ juice of papaya. The plate was kept for $1-2 \mathrm{~h}$ to enable diffusion of the yeast suspension. Subsequently, $0.02 \mathrm{~mL}$ spore suspension of C. gloeosporioides $\left(5 \times 10^{4}\right.$ spores $\left.\mathrm{mL}^{-1}\right)$ was injected into the well. Sterile distilled water was added, instead of the yeast cell suspension, to the control plate. After incubation at $28 \pm 2{ }^{\circ} \mathrm{C}$ for seven days, the fungal growth in each plate was observed and the diameters of the fungal growth measured. This experiment was done using five replicates for each treatment.

\subsubsection{In Vivo Assay}

Healthy papaya fruits cv. Solo, within the weight range of $0.3-0.45 \mathrm{~kg}$ and at color index two (green with a trace of yellow), were washed before being soaked in sodium hypochlorite $0.5 \%$ for $5 \mathrm{~min}$, followed by soaking in sterile distilled water for $1 \mathrm{~min}$. After being air dried, the fruits were surface-sterilized with $70 \%(v / v)$ ethanol. Two wounds were then inflicted on each fruit with a sterile cork borer and $0.02 \mathrm{~mL}$ antagonistic yeast suspension $\left(5 \times 10^{6}\right.$ cells $\left.\mathrm{mL}^{-1}\right)$ applied to the wounds. After $2 \mathrm{~h}, 0.02 \mathrm{~mL}$ of C. gloeosporioides spore suspension $\left(5 \times 10^{4}\right.$ spores $\left.\mathrm{mL}^{-1}\right)$ was placed on the wounds. For the control treatment, only C. gloeosporioides was inoculated onto the wounds. The fruits were stored at room temperature $\left(28 \pm 2{ }^{\circ} \mathrm{C}\right)$ in plastic containers covered with polyethylene plastic. Disease development was recorded after six days by measuring the diameter of the lesions formed. The average lesion expansion and percentage of disease reduction over the control was then calculated using the following formulae $[18,19]$ :

$$
\begin{aligned}
& \text { Lesion expansion average }\left(\mathrm{cm} \text { day }^{-1}\right)= \\
& \frac{\text { Lesion diameter day } 6(\mathrm{~cm})-\text { Lesion diameter on day } 0(\mathrm{~cm})}{\sum \text { storage day }(6 \text { days })}
\end{aligned}
$$

Disease reduction over control percentage $(\%)=$

$$
\frac{\text { Lesion diameter of control fruit }(\mathrm{cm}) \text {-Lesion diameter of treated fruit }(\mathrm{cm})}{\text { Lesion diameter of control }} \times 100
$$

This experiment was conducted using six replicates for each treatment.

\subsubsection{Inhibition of C. gloeosporioides Spore Germination}

The effects of the different yeast cell concentrations on pathogen spore germination was tested using the method described by Droby et al. [20], with minor modifications. Five milliliters of potato dextrose broth (PDB) was poured into sterile glass tubes. Then, $0.1 \mathrm{~mL}$ of the treatment and pathogen spore suspension $\left(5 \times 10^{4}\right.$ spores $\left.\mathrm{mL}^{-1}\right)$ were added into each tube simultaneously. Treatments used in this study were $5 \times 10^{4}, 5 \times 10^{6}$, and $5 \times 10^{8}$ cells $\mathrm{mL}^{-1}$ for isolates F001 and FL013, while Benocide 50WP ${ }^{\circledR}$ (BEN, active ingredient: benomyl 50\% WP, at the concentration of $0.33 \mathrm{~g} \mathrm{~L}^{-1}$ ) and sterile distilled water (SDW) served as the positive and negative controls respectively. All the treated tubes were placed on a rotary shaker at $3 \times g$ at $28{ }^{\circ} \mathrm{C}$ for $20 \mathrm{~h}$. After $20 \mathrm{~h}$ of incubation, 100 random pathogen spores were examined under a light microscope (Standard 25, Carl Zeiss, Oberkochen, Germany) and the germination rate calculated. This experiment was carried out using three replicates for each treatment.

\subsubsection{Production of Diffusible Antagonist Substance}

The diffusible antagonistic substance produced by the yeast was determined according to methods the described by Rahman et al. [21], with minor modifications. Sandwich plates 
were prepared using two types of media. Ten milliliters of PDA was first placed into each petri dish as a bottom layer. A filter paper (Whatman filter paper no. 1) was then placed on the top of the PDA layer and $10 \mathrm{~mL}$ of molten NYDA poured on top of it. After the top layer had solidified, $0.1 \mathrm{~mL}$ of F001 and FL013 suspension at $5 \times 10^{8}$ cells mL $\mathrm{mL}^{-1}$ was poured and spread over the surface of the NYDA in the sandwich plate. After three days of incubation, the NYDA medium inoculated with the yeast and the filter paper layers were removed leaving only the PDA layer on the plates. Then, the PDA layer was inoculated with a mycelial disk of a seven days old culture of $C$. gloeosporioides. The plate was then incubated at $28 \pm 2{ }^{\circ} \mathrm{C}$. After seven days, the radial growth of the fungus was measured. A control treatment was also carried out by substituting sterile distilled water for the yeast suspension. The results were expressed using the average diameter of the $C$. gloeosporioides growth for all treatments. This experiment was conducted using five replicates for each treatment.

\subsection{Identification of Antagonistic Yeast}

Genomic DNA extraction of the most effective yeast was performed using the CTAB methods described by Edwards et al. [22], with minor modifications. Amplification of ribosomal DNA (rDNA) of yeast strain F001 was performed according to the method described by White et al. [23], using universal primers ITS1 (5'-TCCGTAGGTGAACCTGCGG-3') as the forward primer and ITS4 (5'-TCCTCCGCTTAATTGATATGC- $\left.3^{\prime}\right)$ as the reverse primer, synthesized at First Base Laboratories Sdn. Bhd., Malaysia. PCR reaction was performed according to the protocol described by Hata et al. [24]. The amplification was performed in a BioRad iCycler (Bio-Rad) thermocycler as described by Nghia et al. [25].

The PCR product was purified using Qiaquick PCR Purification Kit (Qiagen, Hilden, Germany). The purified PCR product was then sent to NextGene Sdn. Bhd., Malaysia for sequencing. The resulting sequences were aligned and identified using the Basic Local Alignment Search Tool (BLAST) from the National Center for Biotechnology Information (NCBI). Multiple sequence alignment was performed using Clustal W, and phylogenetic analysis constructed by Neighbour Joining method using MEGA software version 6 . Bootstrap values illustrated on the phylogenetic dendrogram were generated with 1000 replicates [26,27]. The isolate was deposited in the Microbial Collection Unit (UNiCC) of the Institute of Biosciences (IBS), Universiti Putra Malaysia. Identification of yeast was also done by referring to morphology characteristics.

\subsection{In Vivo Efficacy of Selected Antagonistic Yeast in Controlling Anthracnose Disease in Papaya Fruit}

The papaya fruit, 'Solo' variety, used for this study was chosen and sanitized as described in Section 2.2.3. After being air dried, the fruit was subjected to dipping treatment with: (i) sterile distilled water and (ii) T. asahii. The treated fruits were then dried, and wrapped individually with clean white paper and packed into corrugated paper boxes before being stored at $28 \pm 2{ }^{\circ} \mathrm{C}$ for eight days. This experiment was conducted with four replications for each treatment. After eight days of storage, the development of anthracnose disease symptoms and its severity on the fruit surfaces were observed and recorded. Disease incidence and severity were calculated using the following formula and scale.

$$
\text { Disease incidence }(\%)=\frac{\text { Number of infected fruit }}{\text { Total number of fruit }} \times 100
$$

Data on disease severity (DS) was indexed on a $0-4$ scale, where, $0=$ no disease symptoms or infection on the fruit surface area, $1=1-10 \%$ area of disease or infection, $2=11-20 \%$ area of disease or infection, $3=21-30 \%$ area of disease or infection and $4=31 \%$ and above area of disease or infection [28]. Disease severity was calculated using the following formula, as described by Singh [29]: 
Disease severity, DS $(\%)=\frac{\sum(\text { Severity rating } \times \text { number of fruit with that rating })}{\text { Total number of fruits assessed } x \text { highest scale }} \times 100$

The fruit pulp from this study was used for enzyme activity determination. The fruits were individually chopped, ground, and freeze-dried using liquid nitrogen. The samples were stored in sealed polyethylene bags at $-80^{\circ} \mathrm{C}$ until ready for extraction.

\subsection{Effects of Yeast Application on Selected Defensive Enzyme Activities}

\subsubsection{Tissue Extraction and Determination of Polyphenol Oxidase (PPO)} Enzyme Activities

All enzyme extraction procedures were carried out at $4{ }^{\circ} \mathrm{C}$. The method of extraction was adapted from Venkatachalam and Meenune [30] with minor modifications. Two grams of frozen papaya pulp tissues were ground with $10 \mathrm{~mL}$ of cold $0.2 \mathrm{M}$ sodium phosphate buffer (pH 6.4) and homogenized using a mortar and pestle at $4{ }^{\circ} \mathrm{C}$. The homogenate was filtered through a layer of cheesecloth and the filtrate centrifuged at $3360 \times \mathrm{g}$ for $30 \mathrm{~min}$ at $4{ }^{\circ} \mathrm{C}$. The supernatant was collected for PPO activity assay, according to the method by Tian et al. [31]. The reaction mixture contained $1.5 \mathrm{~mL}$ of $0.5 \mathrm{M} 4$-methylcatechol in $0.2 \mathrm{M}$ sodium phosphate buffer ( $\mathrm{pH}$ 6.4) and $0.05 \mathrm{~mL}$ of the crude enzyme extract. The absorbance was measured at $398 \mathrm{~nm}$ at $25^{\circ} \mathrm{C}$ for $1 \mathrm{~min}$ using UV/VIS spectrophotometer (Thermo Scientific Multiskan Go, Vantaa, Finland equipped with Thermo Scientific SkanIt Software version 3.2, Vantaa, Finland).

One unit of PPO activity is defined as the amount of enzyme extracts producing an increase in absorbance for $1 \mathrm{~min}$. The enzyme activity is expressed as changes in the absorbance unit $\mathrm{g}^{-1}$ tissue according to the formula described by Kokkinakis and Brooks [32] as follows:

$$
\text { Unit } \mathrm{g}^{1} \text { tissue }=\frac{\text { optical density } \times \text { dilution factor }}{\mathrm{g} \text { of tissue used in the assay }} \times 100
$$

2.5.2. Tissue Extraction and Determination of Phenylalanine Ammonia-Lyase (PAL) Enzyme Activities

For the PAL assay, $2 \mathrm{~g}$ of pulp tissue was homogenized in $4 \mathrm{~mL}$ of $0.1 \mathrm{M}$ sodium borate buffer ( $\mathrm{pH}$ 8.0) solution containing $0.2 \mathrm{~g}$ of insoluble polyvinylpyrrolidone (PVP), $5 \mathrm{mM}$ mercaptoethanol and $2 \mathrm{mM}$ ethylenediaminetetraacetic acid (EDTA). Then, the homogenate was centrifuged for $20 \mathrm{~min}$ at $4{ }^{\circ} \mathrm{C}$ and $17,500 \times g$ [30]. PAL activity was determined according to the method of Jiang and Joyce [33], with slight alterations. An aliquot $(0.1 \mathrm{~mL})$ of the enzyme extract was incubated together with $2.9 \mathrm{~mL}$ of $0.1 \mathrm{M}$ sodium borate buffer ( $\mathrm{pH}$ 8.0) solution containing $3 \mathrm{mM} \mathrm{L}$-phenylalanine for $1 \mathrm{~h}$ at $37^{\circ} \mathrm{C}$. An increase in PAL activity at $290 \mathrm{~nm}$, due to the formation of trans-cinnamate, was measured using UV/VIS spectrophotometer (Thermo Scientific Multiskan Go, Vantaa, Finland, Finland equipped with Thermo Scientific SkanIt Software version 3.2, Vantaa, Finland). One unit of enzyme activity is defined as the amount of enzyme causing a decrease in absorbance of 0.01 per min. The results were expressed as unit $\mathrm{g}^{-1}$ tissue.

\subsubsection{Tissue Extraction and Determination of Catalase (CAT) Enzyme Activities}

Crude extract for CAT activity was obtained using the method of Wang et al. [34]. Two grams of pericarp tissues were homogenized in $4 \mathrm{~mL}$ cold $50 \mathrm{mM}$ sodium phosphate buffer ( $\mathrm{pH}$ 7.0) containing $0.1 \mathrm{~g}$ of polyvinyl polypyrrolidonfe (PVPP). The homogenate was then centrifuged $\left(4^{\circ} \mathrm{C}, 17,500 \times g, 20 \mathrm{~min}\right)$ following which the supernatant was immediately analyzed. Determination of CAT activity was performed according to the method described by Beers and Sizer [35], with slight modifications. The reaction mixture consisted of $0.5 \mathrm{~mL}$ enzyme extract, $2 \mathrm{~mL}$ of $50 \mathrm{mM}$ sodium phosphate buffer ( $\mathrm{pH} 7.0$ ) and $0.5 \mathrm{~mL}$ of $40 \mathrm{mM}$ hydrogen peroxide $\left(\mathrm{H}_{2} \mathrm{O}_{2}\right)$ with a total volume of $3.0 \mathrm{~mL}$. The decomposition of $\mathrm{H}_{2} \mathrm{O}_{2}$ was measured using UV/VIS spectrophotometer (Thermo Scientific Multiskan Go, Vantaa, 
Finland equipped with Thermo Scientific SkanIt Software version 3.2, Vantaa, Finland) at $240 \mathrm{~nm}$ absorbance.

One unit of enzyme activity was defined as micromoles of hydrogen peroxide, oxidized per milliliter per minute at $25{ }^{\circ} \mathrm{C}$. The results were expressed as enzyme unit per gram fresh weight $\left(\mathrm{U} \mathrm{g}^{-1} \mathrm{FW}\right)$. The extinction coefficient of $39.4 \mathrm{mM} \mathrm{cm}^{-1}$ was used to calculate the CAT activity.

\subsection{Yeast Interaction and Attachment to the Pathogen and Papaya Peel}

Attachment of the antagonistic yeast to the pathogen and papaya peel was studied using a scanning electron microscope (SEM), with reference to the methods used by Hasan [15], with minor adjustments. A matured green papaya was washed with tap water and its surface sterilized with 75\% ethanol. After being air dried, the center of the fruit was wounded with a sterile needle and it was then dipped in F001 suspension $\left(5 \times 10^{8}\right.$ cells $\left.\mathrm{mL}^{-1}\right)$ for $3 \mathrm{~min}$. Then, $100 \mu \mathrm{L}$ of pathogen spore suspension at $5 \times 10^{4}$ spores $\mathrm{mL}^{-1}$ was inoculated into the wounded area and the fruit stored at $28 \pm 2{ }^{\circ} \mathrm{C}$ for three days in a covered plastic tray. For the control fruit, there was no pathogen inoculated into the wound. After three days, the fruit's peel at the wounded area was removed and cut into $2 \mathrm{~mm}^{3}$ pieces and then fixed using $2.5 \%$ buffered glutaraldehyde for $24 \mathrm{~h}$ at $4{ }^{\circ} \mathrm{C}$. The sample was then washed with $0.1 \mathrm{M}$ sodium cacodylate buffer $(\mathrm{pH} 7.7)$ and post-fixed in $1 \%$ sodium tetraoxide for $2 \mathrm{~h}$ at $4{ }^{\circ} \mathrm{C}$. Subsequently, the sample was washed again with $0.1 \mathrm{M}$ sodium cacodylate buffer, for three times at $10 \mathrm{~min}$ each. A series of dehydration processes were performed with eight different concentrations of ethanol $(30,40,50,60,70$, 80,90 and $100 \%$ ) for $30 \mathrm{~min}$ each. The samples were dried in a Baltec 030 Critical Point Drying apparatus and affixed onto an aluminium stub and coated with gold in a Polaron Sputter Coater and viewed under SEM (JSM 6400, JOEL, Akishima, Japan).

\subsection{Experimental Design and Statistical Analysis}

The experiment was conducted using a completely randomized design. The results were analyzed using analysis of variance, SAS version 9.4 (SAS Institute, Cary, NC, USA) and the means were compared using Duncan's multiple range test (DMRT) at $p \leq 0.05$. Data for disease incidence and severity percentage were log-transformed before analysis.

\section{Results}

\subsection{Isolation of Antagonistic Yeast from the Papaya Plant}

A total of 110 yeasts strains were isolated from the leaves, petioles, and fruit surfaces of randomly selected papaya plants based on different colony colors, sizes and shapes. All the isolates were preserved and maintained for further assessment of their antagonistic activities against $C$. gloeosporioides.

\subsection{Screening of Antagonist Yeast Against C. gloeosporioides}

Using dual culture screening, the antagonistic activities of the yeast strains were measured by their abilities to resist fungal invasion or inhibit fungal growth before yeast streaking. Out of the 110 yeast isolates, only 25 were found to have positive antagonistic effects against $C$. gloeosporioides, after being co-cultivated in the same agar plate. All 25 yeast strains showed different degrees of antagonistic activity as illustrated by the PIRG values after seven days of incubation. Out of the 25 yeast strains selected, only five isolates, namely, F001, F006, L003, FL013 and LP010, had more than 55\% inhibitory effects compared to the control (0\%). The PIRG of strains F001, F006 and FL013 were 59.5, 60.8 and 70.3, respectively, and 59.5\% for L003 and LP010, after seven days of incubation (Table 1 and Figure 1). 
Table 1. Effects of antagonist yeast isolates on radial growth of $C$. gloeosporioides in dual culture assay after seven days incubation at $28 \pm 2{ }^{\circ} \mathrm{C}$.

\begin{tabular}{cc}
\hline Yeast Isolate & $\begin{array}{c}\text { Percentage Inhibition of Radial Growth } \\
\text { (PIRG) (\%) }\end{array}$ \\
F001 & $59.46 \pm 5.41 \mathrm{abc}$ \\
F002 & $50.00 \pm 4.05 \mathrm{bcde}$ \\
F006 & $60.81 \pm 1.35 \mathrm{ab}$ \\
F010 & $28.38 \pm 1.35 \mathrm{hi}$ \\
F015 & $45.95 \pm 2.70 \mathrm{cdef}$ \\
F022 & $32.43 \pm 2.70$ ghi \\
F026 & $54.05 \pm 0.00 \mathrm{bcde}$ \\
L003 & $59.46 \pm 8.11 \mathrm{abc}$ \\
FL002 & $31.08 \pm 1.35$ ghi \\
FL006 & $35.14 \pm 2.70 \mathrm{fgh}$ \\
FL013 & $70.27 \pm 0.00 \mathrm{a}$ \\
FL015 & $36.49 \pm 1.35 \mathrm{fgh}$ \\
FL016 & $54.05 \pm 0.00 \mathrm{bcde}$ \\
FP001 & $40.54 \pm 2.70 \mathrm{efgh}$ \\
FP002 & $54.05 \pm 0.00 \mathrm{bcde}$ \\
FP006 & $54.05 \pm 2.70 \mathrm{bcde}$ \\
FP013 & $36.49 \pm 1.35 \mathrm{fgh}$ \\
FP014 & $51.35 \pm 2.70 \mathrm{bcde}$ \\
LP005 & $41.89 \pm 1.35 \mathrm{defg}$ \\
LP010 & $59.46 \pm 8.11 \mathrm{abc}$ \\
FLP004 & $33.78 \pm 4.05 \mathrm{fghi}$ \\
FLP007 & $54.05 \pm 0.00 \mathrm{bcde}$ \\
FLP009 & $52.03 \pm 2.03 \mathrm{bcde}$ \\
FLP011 & $21.62 \pm 2.70 \mathrm{i}$ \\
FLP016 & $50.00 \pm 1.35 \mathrm{bcde}$ \\
\hline
\end{tabular}

${ }^{\bar{z}}$ Means values within each column followed by different letter indicate significant differences between treatments according to DMRT $(p \leq 0.05)$. Values after \pm represent the standard error (SE).
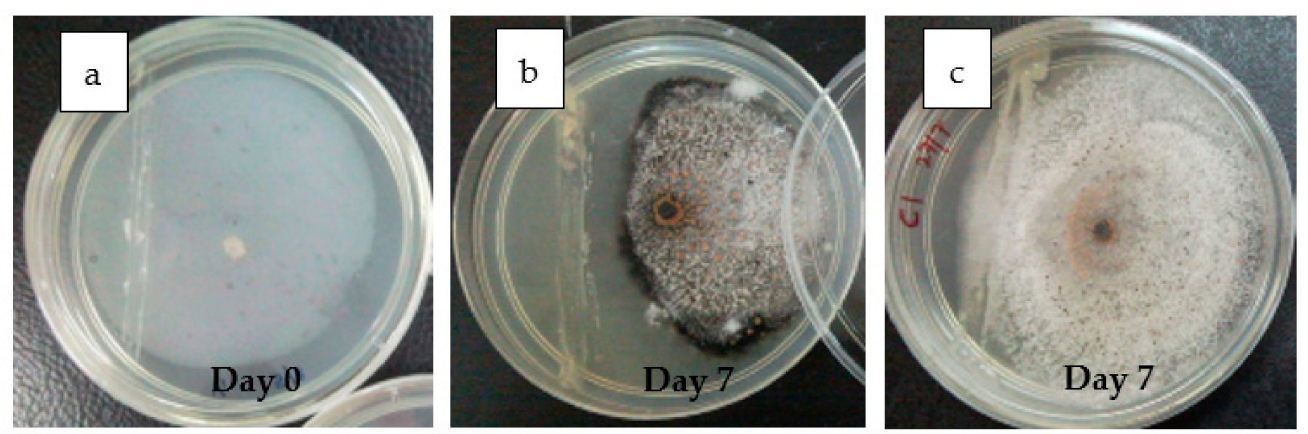

Figure 1. Radial growth of $C$. gloeosporioides co-cultured with antagonist yeast after seven days at $28 \pm 2{ }^{\circ} \mathrm{C} ;(\mathbf{a}, \mathbf{b}) \mathrm{C}$. gloeosporioides co-cultured with LP010 and (c) C. gloeosporioides co-cultured with FLP011.

\subsection{Effect of Yeast Suspension on C. gloeosporioides Growth in Agar Well Test}

Five potential yeast strains selected from the previous screening were further evaluated in agar well tests. Among these selected yeast strains, LP010 showed the lowest ability for spore inhibition (Table 2), whereas yeast suspension of F001, F006, and L003 did not show significant differences in the inhibition of $C$. gloeosporioides spores. Meanwhile, FL013 yeast suspension showed remarkable ability to totally inhibit the growth of C. gloeosporioides. This experiment showed that FL013 had the most robust antagonistic activity, followed by strains F006, F001, L003, and LP010, in that order. 
Table 2. Antagonistic effects of yeast suspension on mycelial growth of C. gloeosporioides in agar well tests after seven days incubation at $28 \pm 2{ }^{\circ} \mathrm{C}$.

\begin{tabular}{cc}
\hline Treatment & Diameter of Mycelial Growth (cm) \\
\hline Control & $6.82 \pm 0.20 \mathrm{a}^{\mathrm{z}}$ \\
F001 & $1.96 \pm 0.88 \mathrm{c}$ \\
F006 & $0.80 \pm 0.35 \mathrm{~cd}$ \\
L003 & $2.25 \pm 0.33 \mathrm{c}$ \\
FL013 & $0.00 \pm 0.00 \mathrm{~d}$ \\
LP010 & $4.73 \pm 0.37 \mathrm{~b}$ \\
\hline
\end{tabular}

${ }_{\mathrm{z}}$ Means values within each column followed by different letters indicate significant differences between treatments according to DMRT $(p \leq 0.05)$. Values after \pm represent SE.

\subsection{Effect of Antagonist Yeast on In Vivo Anthracnose Disease Control}

Many researchers prefer Agar-based screening of potential biocontrol agents to select the most probable candidates due to cost and time factors [21,36,37]. It is also an excellent approach to validate the results obtained from other in vitro screening tests. However, in vivo studies are still needed to verify the results obtained, even after several in vitro screening studies have been done. This study (Table 3) showed that all wounds on the papayas treated with the yeasts had significantly smaller anthracnose lesion diameters than the control, except for isolates L003 and LP010. The results for isolate F001 showed the highest biocontrol efficacy with only $1.99 \mathrm{~cm}$ lesion diameter, $0.33 \mathrm{~cm}^{\text {day }}{ }^{-1}$ lesion expansion rate, and $51.19 \%$ disease reduction as compared to the control (Figure 2).

Table 3. Effects of antagonist yeast treatments in papaya inoculated with C. gloeosporioides afterstorage at $28 \pm 2{ }^{\circ} \mathrm{C}$ for six days.

\begin{tabular}{cccc}
\hline Treatment & Lesion Diameter $\mathbf{( c m )}$ & $\begin{array}{c}\text { Lesion Expansion } \\
\text { (cm day }\end{array}$ & $\begin{array}{c}\text {-1) } \\
\text { Disease Reduction } \\
\text { over Control (\%) }\end{array}$ \\
\hline Control & $4.08 \pm 0.06 \mathrm{a}^{\mathrm{z}}$ & $0.68 \pm 0.01 \mathrm{a}$ & - \\
F001 & $1.99 \pm 0.17 \mathrm{~d}$ & $0.33 \pm 0.03 \mathrm{~d}$ & $51.19 \pm 4.17 \mathrm{a}$ \\
F006 & $3.45 \pm 0.22 \mathrm{bc}$ & $0.58 \pm 0.04 \mathrm{bc}$ & $15.44 \pm 5.48 \mathrm{bc}$ \\
L003 & $3.68 \pm 0.08 \mathrm{ab}$ & $0.61 \pm 0.01 \mathrm{ab}$ & $9.93 \pm 1.94 \mathrm{c}$ \\
FL013 & $3.13 \pm 0.19 \mathrm{c}$ & $0.52 \pm 0.03 \mathrm{c}$ & $23.20 \pm 4.77 \mathrm{~b}$ \\
LP010 & $3.62 \pm 0.14 \mathrm{ab}$ & $0.60 \pm 0.02 \mathrm{ab}$ & $11.36 \pm 3.37 \mathrm{bc}$ \\
\hline
\end{tabular}

${ }_{\mathrm{z}}$ Mean values within each column followed by different letters indicate significant differences between treatments according to DMRT $(p \leq 0.05)$. Values after \pm represent SE.
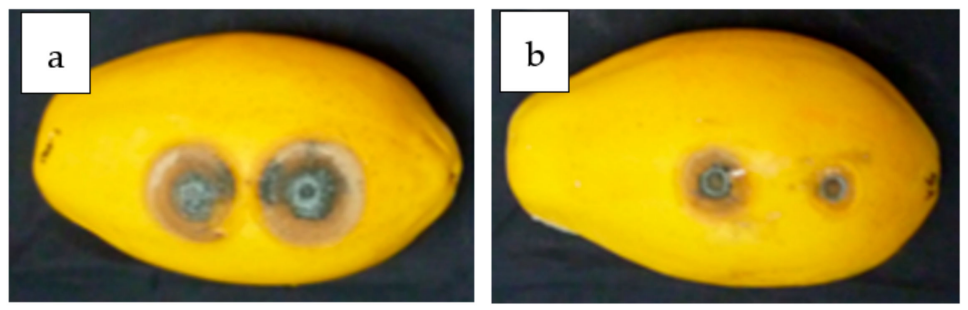

Figure 2. Radial growth of C. gloeosporioides in papaya wounds treated with antagonist yeast after six days of inoculation; (a) papaya wound without yeast treatment, (b) papaya wound treated with F001 yeast.

\subsection{Effects of Antagonist Yeast Concentrations on C. gloeosporioides Spore Germination}

The ability of the biocontrol treatments at different concentrations in suppressing the germination of fungal spore was investigated. Only two isolates were chosen for this study, F001 and FL013, based on their effectiveness as biological agents in previous tests. Treatments with these two isolated yeasts significantly reduced C. gloeosporioides spore germination percentages compared to distilled water (Table 4). The spore germi- 
nation percentages were shown to decrease significantly, from $90 \%$ to $30 \%$ for the F001 isolate and from $76 \%$ to $64 \%$ for the FL013 isolate, with increasing yeast cell concentrations. However, the increment in concentration from $5 \times 10^{6}$ to $5 \times 10^{8}$ cells mL ${ }^{-1}$ for yeast isolate FL013 did not demonstrate significant spore germination inhibition. Isolate F001 demonstrated better overall control with the lowest spore germination of $30 \%$ at the $5 \times 10^{8}$ cells $\mathrm{mL}^{-1}$ yeast concentration. Compared to the commercial fungicide, Benocide $50 \mathrm{WP}^{\circledR}$, both yeast isolates showed significantly higher inhibition of spore germination at only $5 \times 10^{6}$ cells $\mathrm{mL}^{-1}$. Due to the better antagonistic results shown for yeast suspension at concentration $5 \times 10^{8}$ cells $\mathrm{mL}^{-1}$, the same concentration was used for the next assessment.

Table 4. Effects of different solutions on spore germination percentage of C. gloeosporioides after $20 \mathrm{~h}$ incubation at $28^{\circ} \mathrm{C}$ in PDB.

\begin{tabular}{cc}
\hline Solution & Spore Germination (\%) \\
\hline Sterile distilled water & $100.0 \pm 0.00 \mathrm{a}^{\mathrm{z}}$ \\
${\text { Benocide } 50 \mathrm{WP}^{\circledR}}^{\circledR}$ & $78.6 \pm 3.62 \mathrm{c}$ \\
F001 $5 \times 10^{4}$ cells mL $^{-1}$ & $89.5 \pm 0.25 \mathrm{~b}$ \\
F001 $5 \times 10^{6}$ cells mL $^{-1}$ & $48.9 \pm 1.41 \mathrm{e}$ \\
F001 $5 \times 10^{8}$ cells mL $^{-1}$ & $30.3 \pm 1.77 \mathrm{f}$ \\
FL013 $5 \times 10^{4}$ cells mL $^{-1}$ & $76.2 \pm 1.16 \mathrm{c}$ \\
FL013 $5 \times 10^{6}$ cells mL $^{-1}$ & $67.0 \pm 4.15 \mathrm{~d}$ \\
FL013 $5 \times 10^{8}$ cells mL $^{-1}$ & $64.3 \pm 2.99 \mathrm{~d}$ \\
\hline
\end{tabular}

$\overline{\mathrm{z}}$ Mean values with different letters within each column are significantly different at $p \leq 0.05$ using DMRT. Values after \pm represent SE.

\subsection{Diffusible Compound Production by Antagonist Yeast}

The ability to produce antifungal metabolites is one of the biocontrol mechanisms of antagonist organisms. This study showed that both yeast strains significantly inhibited fungal mycelial growth compared to the control (Table 5). Mycelial growth was completely inhibited by diffusible antifungal substances produced by isolate F001 at the concentration of $5 \times 10^{8}$ cells $\mathrm{mL}^{-1}$. However, $C$. gloeosporioides mycelia could still survive on PDA containing diffusible antifungal substances produced by isolate FL013. It was observed that the diffusible compounds produced by isolate F001 were more potent than FL013 as demonstrated by its better control of fungal growth.

Table 5. Effects of diffusible substances generated by antagonist yeasts on C. gloeosporioides mycelia growth diameter after seven days incubation at $28^{\circ} \mathrm{C}$.

\begin{tabular}{cc}
\hline Treatment & Mycelia Growth Diameter $(\mathbf{c m})$ \\
\hline Sterile distilled water (SDW) & $6.91 \pm 0.09 \mathrm{a}^{\mathrm{z}}$ \\
F001 $5 \times 10^{8}$ cells mL $^{-1}$ & $0.00 \pm 0.00 \mathrm{c}$ \\
FL013 $5 \times 10^{8}$ cells $\mathrm{mL}^{-1}$ & $5.69 \pm 0.50 \mathrm{~b}$ \\
\hline
\end{tabular}

$\overline{{ }^{z}}$ Mean values with the different letters within each column are significantly different at $p \leq 0.05$ using DMRT. Values after \pm represent SE.

\subsection{Antagonist Yeast Identification}

Following in vitro and in vivo screenings, isolate F001 was found to be stable and effective in both the controlled environment (in vitro) and natural environment (in vivo). Thus, only this isolate was identified and further tested for its biocontrol ability against C. gloeosporioides. The DNA of antagonist yeast F001 was successfully extracted using the CTAB method. The ITS region was amplified using a pair of universal primers, ITS1 and ITS4. After amplification, a product of $527 \mathrm{bp}$ was obtained from the isolate. The sequence obtained was deposited in the GenBank and used to search for similar sequences in various databanks using the BLAST program. The phylogenetic tree generated using the Neighbour Joining (NJ) method showed that isolate F001 has high homology (99\%) to 
Trichosporon asahii (accession number: KX580068) and was clustered together with other sequences of T. asahii as evidence of high homology (99\%). However, there are minor variations between T. asahii and T. inkin, as visualized by the cluster separation illustrated in Figure 3.

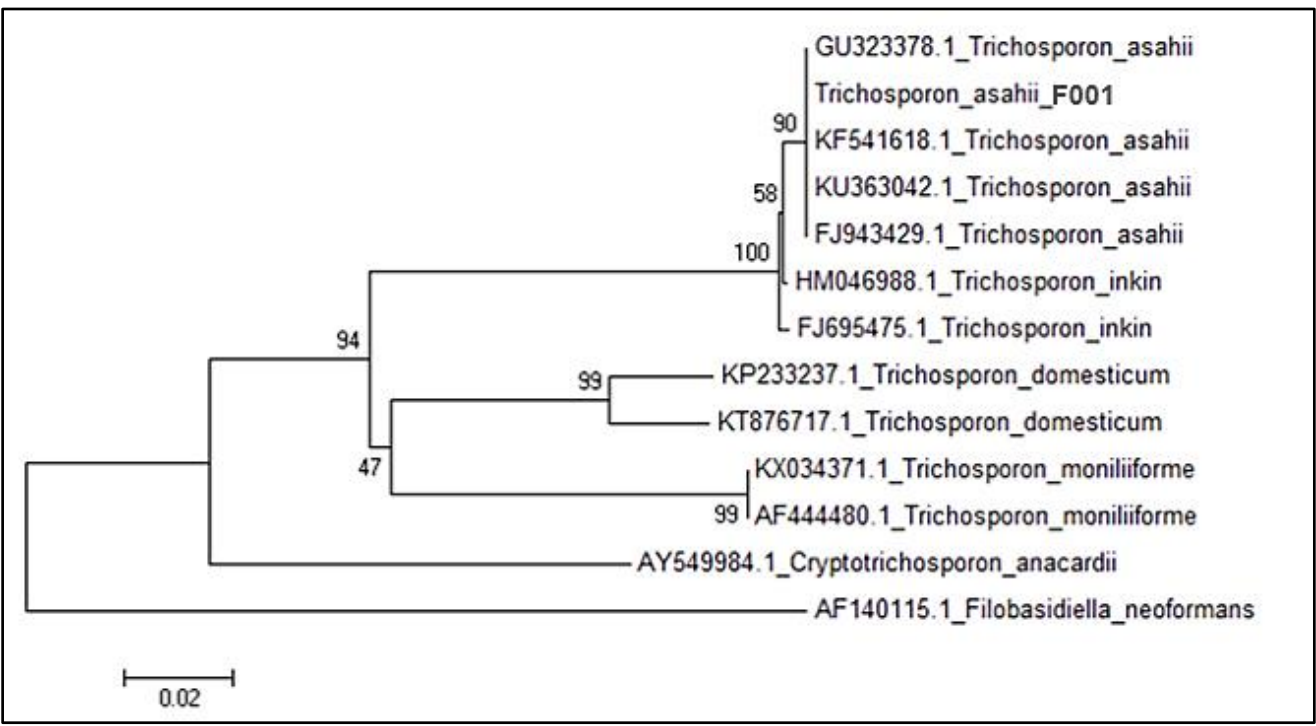

Figure 3. Phylogenetic tree based on ITS rDNA sequence of Trichosporon asahii F001 and reference sequences of Trichosporon with outgroup genus Cryptotrichosporon and Filobasidiella. Tree generated using Neighbour Joining analysis with 1000 bootstrap simulations. Numbers on the branches represent bootstrap values.

BLAST comparison of the ribosomal DNA sequences from the selected yeast strain showed that isolate F001 had 99\% similarity to the sequences of Trichosporon asahii. Observation of the morphological (colony morphology) and microscopic (cell shape and size) characteristics of T. asahii supports the rDNA sequencing results through referring Kurtzman and Fell [38]. The yeast colony of the F001 strain, identified as T. asahii, was white, with a wide, dry, fine zonate margin and farinose at the center (Figure 4a). Culture odor was lacking or faintly cheese-like and the colony diameter was around 16-24 mm. Meanwhile, the yeast cells in Figure $4 \mathrm{~b}$ showed chains of spores in different shapes which were round, rectangular or irregular. All of the morphological and microscopic characteristics shown by the selected isolate cell matched with T. asahii characteristics.
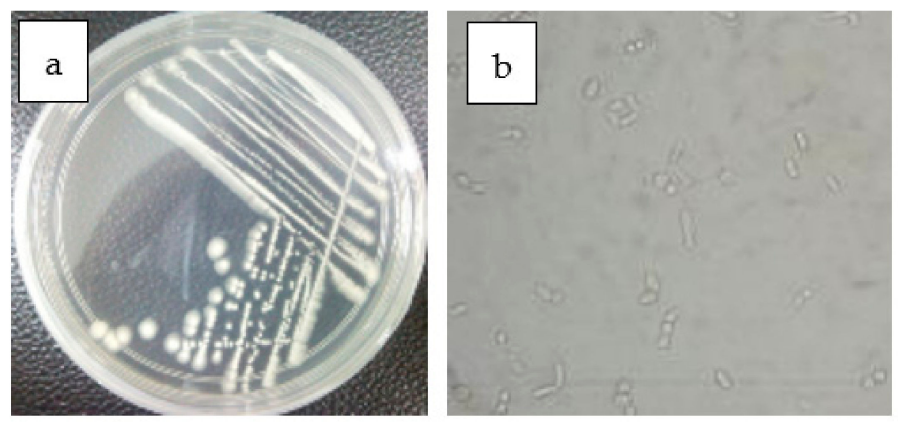

Figure 4. Morphological characterization of T. asahii; (a) T. asahii on PDA plate, (b) T. asahii cell shape. 


\subsection{Disease Incidence and Severity in Papaya Treated with Antagonist Yeast}

After eight days of storage, the disease incidence on the naturally infected fruits treated with T. asahii showed no significant difference as compared with the control treatments (Table 6). However, in terms of disease severity, the fruit treated with T. asahii showed significantly lower severity percentage than that in the control fruit, which was $50 \%$ reduction. With reference to the results, although T. asahii was unable to avoid disease incidence significantly, it still managed to reduce the severity of the disease on the papaya.

Table 6. Effects of treatments (sterile distilled water and Trichosporon asahii) on disease incidence and severity percentage on Solo papaya (Carica papaya L.) stored at $28^{\circ} \mathrm{C}$ for eight days.

\begin{tabular}{ccc}
\hline Treatment & Disease Incidence (\%) & Disease Severity (\%) \\
\hline Sterile distilled water & $100 \pm 0.00 \mathrm{a}^{\mathrm{z}}$ & $75 \pm 13.7 \mathrm{a}$ \\
Trichosporon asahii & $66.7 \pm 14.43 \mathrm{a}$ & $25 \pm 9.1 \mathrm{~b}$
\end{tabular}

${ }^{\bar{z}}$ Mean values within each column followed by different letters indicate significant differences between treatments according to DMRT $(p \leq 0.05)$. Values after \pm represent SE.

\subsection{Polyphenol Oxidase (PPO), Phenylalanine Ammonia-Lyase (PAL), Catalase (CAT) Enzyme Activity}

Defense-related enzymes measured for this study were PPO, PAL and CAT. After eight days of storage, the PPO enzyme activities in Solo papaya treated with T. asahii showed no significant difference with the control treatments (Table 7). There was also no significant difference shown for the other two enzymes measured: PAL and CAT.

Table 7. Effects of treatments (sterile distilled water and Trichosporon asahii) on polyphenol oxidase (PPO), phenylalanine ammonia-lyase (PAL) and catalase (CAT) on Solo papaya (Carica papaya L.) during storage at $28^{\circ} \mathrm{C}$ for eight days.

\begin{tabular}{cccc}
\hline Treatment & $\begin{array}{c}\text { PPO } \\
\text { (Unit }^{-\mathbf{1}} \text { Tissue) }\end{array}$ & $\begin{array}{c}\text { PAL } \\
\text { (Unit } \mathbf{~}^{-\mathbf{1}} \text { Tissue) }\end{array}$ & $\begin{array}{c}\text { CAT } \\
\text { (U }^{-\mathbf{1}} \text { FW) }\end{array}$ \\
\hline Sterile distilled water & $274.6 \pm 4.8 \mathrm{a}^{\mathrm{z}}$ & $2012.7 \pm 11.4 \mathrm{a}$ & $2.34 \pm 0.3 \mathrm{a}$ \\
Trichosporon asahii & $274.3 \pm 5.9 \mathrm{a}$ & $1986.0 \pm 13.6 \mathrm{a}$ & $2.27 \pm 0.4 \mathrm{a}$ \\
\hline
\end{tabular}

${ }_{\mathrm{z}}$ Means values within each column and factor followed by different letters indicate significant differences between treatments according to DMRT $(p \leq 0.05)$. Values after \pm represent SE.

\subsection{Interaction of Antagonist Yeast and C. gloeosporioides in Papaya}

An ultrastructure study was done to investigate the interaction between T. asahii, the pathogen and the host. As shown in Figure 5b,c, T. asahii and the fungal pathogen exhibited successful colonization on the wounded papaya peel three days after inoculation. Meanwhile, Figure $5 \mathrm{~d}$ illustrates that the T. asahii cells attached tenaciously to the hyphae of $C$. gloeosporioides growing on the wounded papaya peel. 

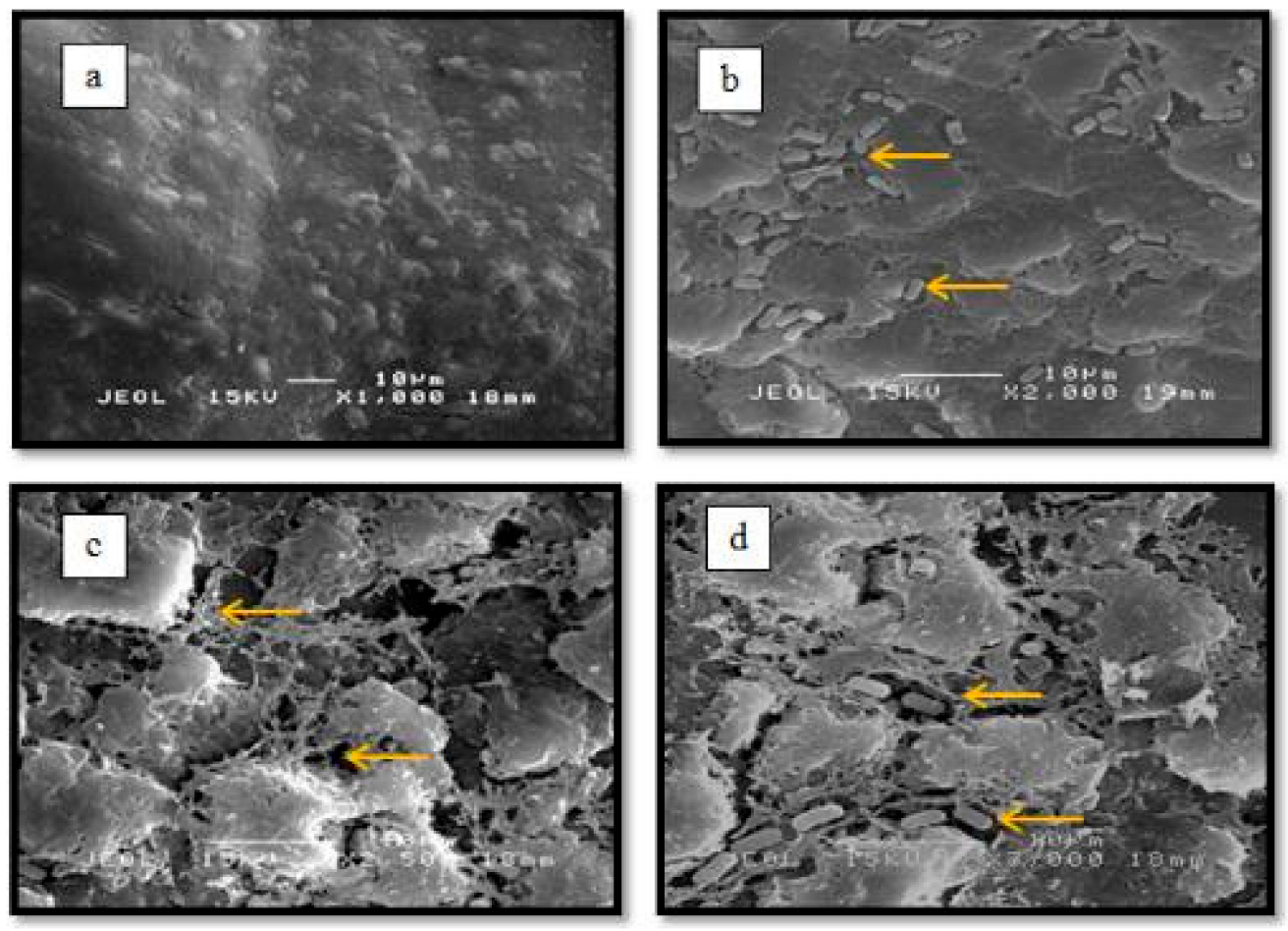

Figure 5. Attachment and interaction of C. gloeosporioides, T. asahii and papaya peel after three days of inoculation, viewed using scanning electron microscope. (a) papaya peel without any inoculation, (b) papaya peel inoculated with T. asahii (arrows show yeast cells), (c) papaya peel inoculated with C. gloeosporioides spores (arrows show fungal hyphae) and (d) papaya peel inoculated with $C$. gloeosporioides and T. asahii (arrows show yeast cells attached to fungal hyphae).

\section{Discussion}

The typical strategy for biocontrol is to use living organisms to suppress or inhibit the growth, infection, or reproduction of another organism [39]. Disease control by exploiting antagonist organisms has become a viable disease management strategy, and several microorganisms have been successfully patented as postharvest biocontrol agents [40-43]. According to Alvinda and Natsuaki [44], the most viable way of using antagonist microorganisms as biocontrol agents is by supporting and maintaining existing antagonists which already reside and are established on the target plant environments. Consequently, epiphytic yeast isolated from the papaya plant may be an optimum choice for the isolation of antagonist agents because of their ability to colonize the papaya fruit naturally. Introducing new antagonist microorganisms to a host may result in undesirable effects such as complexities arising from biocontrol agent and host compatibility. Such biocontrol agents cannot multiply or inhabit the host naturally and may require several applications to maintain effectiveness. Furthermore, study on any possible side effects from introducing new microorganisms to a host needs to be conducted to avoid any new disease outbreaks or adverse impacts on the host and consumers. Thus, exploiting the native antagonist microorganisms as the source biocontrol agents is safer and more reliable than the introduction of new biocontrol agents to the produce.

The establishment of biocontrol products involves screening large numbers of possible antagonists. The selection of appropriate screening methods is essential in determining effective biocontrol agents against pathogenic diseases. Optimally, biocontrol organism candidates should be screened on plants or in vivo rather than on plate or in vitro cultures. However, huge-scale screening study on whole plants is usually time-consuming and labor-intensive, thus the conventional screening approach remains prevalent among researchers [45]. 
In the dual culture assay, out of the 110 yeast strains isolated, only five strains, namely, F001, F006, L003, FL013, and LP010, displayed more than 55\% inhibitory effects compared to the control $(0 \%)$. These five yeast strains were further screened using an agar well test. The results showed that isolates F001 and F006 worked better when immediately in contact with the pathogen but this was not so for LP010. The weaker antagonistic effect of LP010 in the agar well test may be due to it having a different mode of action in controlling pathogens as compared to the other isolates, as suggested by Alvindia and Natsuaki [44], where the antagonist's mode of action is said to influence its capability in preventing the activity of the pathogen tested. For example, the yeast's ability to colonize rapidly and maintain an adequate population level is vital in nutrients competition with pathogens and to maintain its effectiveness in disease suppression [46]. However, in the current study, the actual reason for the outcome was not thoroughly examined since the main focus of this experiment was to screen for potential candidates as antagonist yeast strains against C. gloeosporioides.

Meanwhile, F001 showed better antagonist activity than the other isolates in in vivo screening tests as compared to the in vitro tests. Capdeville et al. [2] also discovered a similar finding where some yeast strains successfully managed the pathogen in vitro but not in vivo. Some successfully managed the disease in vivo but were unable to effect high suppression against the fungus in vitro. In contrast, others managed to control the fungus and the disease in vitro and in vivo. This situation may be due to differences in adaptation of the yeast to the environment, where the in vitro environment was more stable than the in vivo assay. In Vivo the pathogen inoculum amount is difficult to be defined since it is under exposed conditions. Further, postharvest disease infection can be influenced by inoculum in the processing environment and the extent of wounding on fruits after harvest and handling [2].

Biocontrol efficacy of microbial antagonists can be enhanced by the additional density of the antagonists. Quantitative interaction between the concentration of antagonists applied and the resulting effectiveness of the biocontrol agents was also observed in the present study. Zhang et al. [47] also demonstrated that in vitro co-culturing of Pseudozyma fusiformata, Metschnikowia sp., and Aureobasidium pullulans at higher concentrations had a higher significant effect in suppressing spore germination or germ tube elongation of Monilinia laxa, a postharvest pathogen in peach. These scenarios indicate that antagonists and pathogens compete for the same nutrients to survive [48]. However, the additional concentration of FL013 from $5 \times 10^{6}$ to $5 \times 10^{8}$ cells $\mathrm{mL}^{-1}$ unable to significantly reduce spore germination, as shown in the results obtained. According to Sharma et al. [49], this qualitative response is strongly influenced by the antagonist's ability to multiply and spread at the wound site. Studies done by Droby et al. [50] also showed that mutant Pichia guilliermondii lost its antagonist activity against Penicillium digitatum on grapefruit and against Botrytis cinerea on apples even at concentrations of up to $10^{10} \mathrm{CFU} / \mathrm{mL}$. This situation was due to the static cell population of this mutant yeast at the wound sites, while the wild type multiplied 10-20 fold within $24 \mathrm{~h}$. In general, antagonist microbes are most effective as biocontrol agents when applied at $10^{7}$ to $10^{8} \mathrm{CFU} \mathrm{mL} \mathrm{m}^{-1}[17,47,51,52]$, and rarely, higher concentrations are needed [49].

Yeast's antagonistic mode of action also includes the ability to generate antagonistic substances, for example, killer toxins, peptides, and antibiotic metabolites [9,53,54]. Some yeasts display killing activity through secretion of proteins or glycoproteins, killing toxins commonly lethal to other yeast species, pathogenic filamentous fungi, and bacteria through different mechanisms, including hydrolysis of the primary cell wall component $\beta-1,3-$ glucans [55-58]. Yeasts with the ability to secrete killer toxins such as Saccharomyces cerevisiae and Pichia membranifaciens are generally immune to killer toxins of their class and this gives the yeast cells an advantage over their competitors [59-61].

The metabolites from both the yeast strains tested, namely F001 and FL013, were found to have significant inhibitory effects on the pathogen's growth compared to the control. However, diffusible antifungal metabolites produced by isolate F001 had a better effect in 
inhibiting the growth of C. gloeosporioides mycelia compared to FL013. After reference to all the in vitro and in vivo screening tests, only F001, identified as Trichosporon asahii, was chosen for further study as a potential antagonist agent against $C$. gloeosporioides, due to its effectiveness shown in several assessments.

Several studies showed that antagonist yeast could interact with the host tissue to induce production of defensive enzymes after application of the yeast on the fruit surfaces [7]. Chitinase, $\beta$-1,3-glucanase, phenylalanine ammonia-lyase (PAL), catalase $(\mathrm{CAT})$, peroxidase and polyphenol oxidase (PPO) are considered important enzymes in disease resistance mechanisms against pathogens. However, in the present study, the induction of PPO, PAL and CAT were not measurable after the application of T. asahii on the papaya fruit. The results showed that the induction of PPO, PAL and CAT responses are not T. asahii antagonist's mode of action even though the fruit treated with this yeast treatment showed lower disease severity compared to the sterile distilled water treated fruit. Since the disease defensive response of fruit also involves many other types of mechanisms, this situation might be due to the generation of microenvironments that did not favor the growth of pathogens on the treated fruit, such as competition for nutrients and space or direct parasitism of biocontrol agents against the pathogen [62].

Attachment of antagonist microorganisms to the pathogen hyphae is also an essential factor for successful biocontrol activity. With this ability, the biocontrol agent is able to disrupt the pathogen's action to begin infection, thus, controlling lesion development on the produce. The importance of this attribute can be seen in the relationships of Enterobacter cloacae and Rhizopus stolonifer [63], and Pichia guilliermondii and Penicillium italicum [64]. In Vitro studies performed on these relationships showed that antagonistic yeasts and bacteria absorb nutrients faster than target pathogens due to direct attachment, thus preventing spore germination and pathogen growth $[63,65,66]$.

Meanwhile, according to in vitro studies done by Wisniewski et al. [67], yeast attachment on fungal hyphae occurs within 12 to $16 \mathrm{~h}$ of incubation, while for in vivo studies, attachment of yeast to pathogen hyphae, Botrytis spp. was discovered within 48 to $72 \mathrm{~h}$ after inoculation. Considering that most fungal pathogens begin invading the fruit tissue within 6 to $10 \mathrm{~h}$, attachment of antagonist microbes might have limitations in preventing decay if applied after or simultaneously with disease infection [68]. The micrograph obtained in the present study after $48 \mathrm{~h}$ of simultaneous inoculation, shown in Figure $5 \mathrm{~d}$, shows that the pathogen hyphae had already covered the papaya fruit peel, and the yeast was unable to inhibit spore germination. Observation of the attachment effect should be improved by viewing the interaction activity $72 \mathrm{~h}$ after inoculation or by applying the biocontrol earlier, before the pathogen spores are introduced to the papaya peel.

Trichosporon species are widely distributed in nature. Other than being commonly isolated from soil, fruit, and other environmental sources, it is also present in the human gastrointestinal and respiratory tracts $[69,70]$. From the results obtained, T. asahii isolated from the papaya fruit has proven its antagonistic ability against $C$. gloeosporioides and can thus be used to effectively control postharvest anthracnose disease in papaya fruit. The possible mechanisms of action include: (1) space and nutrition competition with C. gloeosporioides; (2) inhibition of pathogen growth by production of diffusible antifungal substances; and (3) direct parasitism against C. gloeosporioides by attachment to the pathogen hyphae to reduce disease severity on the wounded papaya. However, the application of T. asahii on produce needs to be fully elucidated to gain better understanding in manipulating the strain as a biocontrol agent and to avoid any side effects on humans and the environment.

Author Contributions: Conceptualization, M.T.M.M.; methodology, H.H., E.M.H. and N.E.T.; formal analysis, H.H., S.F.Y., E.M.H. and N.E.T.; writing—original draft preparation, H.H., S.F.Y. and N.E.T.; writing-review and editing, M.T.M.M., E.M.H., S.F.Y., N.E.T. and H.H.; supervision, M.T.M.M. All authors have read and agreed to the published version of the manuscript.

Funding: This research received no external funding. 
Data Availability Statement: The data presented in this study are available on request from the corresponding author.

Acknowledgments: The authors wish to thank the staff at the Plant Pathology Laboratory, Universiti Putra Malaysia, for their technical support and material contribution. The authors are also grateful for the collaboration and plant samples from Malaysian Agrifood Corporation (MAFC).

Conflicts of Interest: The authors declare no conflict of interest.

\section{References}

1. Rahman, M.A.; Mahmud, T.M.M.; Kadir, J.; Abdul-Rahman, R.; Begum, M.M. Major postharvest fungal diseases of papaya cv. Sekaki in Selangor, Malaysia. Pertanika J. Trop. Agric. Sci. 2008, 31, $27-34$.

2. Capdeville, G.D., Jr.; Souza, M.T.; Santos, J.R.P.; Miranda, S.d.P.; Caetano, A.R.; Torres, F.A.G. Selection and testing of epiphytic yeasts to control anthracnose in post-harvest of papaya fruit. Sci. Hortic. 2007, 111, 179-185. [CrossRef]

3. Paiva, E.D.; Serradilla, M.J.; Ruiz-Moyano, S.; Córdoba, M.G.; Villalobos, M.C.; Casquete, R.; Hernández, A. Combined effect of antagonistic yeast and modified atmosphere to control Penicillium expansum infection in sweet cherries cv. Ambrunés. Int. J. Food Microbiol. 2017, 241, 276-282. [CrossRef] [PubMed]

4. Hernandez-Montiel, L.G.; Gutierrez-Perez, E.D.; Murillo-Amador, B.; Vero, S.; Chiquito-Contreras, R.G.; Rincon-Enriquez, G. Mechanisms employed by Debaryomyces hansenii in biological control of anthracnose disease on papaya fruit. Postharvest Biol. Technol. 2018, 139, 31-37. [CrossRef]

5. Manso, T.; Nunes, C. Metschnikowia andauensis as a new biocontrol agent of fruit postharvest diseases. Postharvest Biol. Technol. 2011, 61, 64-71. [CrossRef]

6. Carmona-Hernandez, S.; Reyes-Pérez, J.J.; Chiquito-Contreras, R.G.; Rincon-Enriquez, G.; Cerdan-Cabrera, C.R.; HernandezMontiel, L.G. Biocontrol of Postharvest Fruit Fungal Diseases by Bacterial Antagonists: A Review. Agronomy 2019, 9, 121. [CrossRef]

7. Spadaro, D.; Droby, S. Development of biocontrol products for postharvest diseases of fruit: The importance of elucidating the mechanisms of action of yeast antagonists. Trends Food Sci. Technol. 2016, 47, 39-49. [CrossRef]

8. Liu, J.; Sui, Y.; Wisniewski, M.; Droby, S.; Liu, Y. Review: Utilization of antagonistic yeasts to manage postharvest fungal diseases of fruit. Int. J. Food Microbiol. 2013, 167, 153-160. [CrossRef] [PubMed]

9. Droby, S.; Wisniewski, M.; Macarisin, D.; Wilson, C. Twenty years of postharvest biocontrol research: Is it time for a new paradigm? Postharvest Biol. Technol. 2009, 52, 137-145. [CrossRef]

10. Wilson, C.L.; Wisniewski, M.E. Biological control of postharvest diseases of fruit and vegetables: An emerging technology. Annu. Rev. Phytopathol. 1989, 27, 425-441. [CrossRef]

11. Konsue, W.; Dethoup, T.; Limtong, S. Biological Control of Fruit Rot and Anthracnose of Postharvest Mango by Antagonistic Yeasts from Economic Crops Leaves. Microorganisms 2020, 8, 317. [CrossRef]

12. El-Tarabily, K.A.; Sivasithamparam, K. Potential of yeasts as biocontrol agents of soil-borne fungal plant pathogens and as plant growth promoters. Mycoscience 2006, 47, 25-35. [CrossRef]

13. Droby, S.; Chalutz, E. Mode of action of biocontrol agents for postharvest diseases. In Biological Control of Postharvest Diseases of Fruits and Vegetables-Theory and Practice; Wilson, C.L., Wisniewski, M.E., Eds.; CRC Press: Boca Raton, FL, USA, 1994.

14. Arras, G.; Arru, S. Mechanisms of action of some microbial antagonists against fungal pathogens. Ann. Microbiol. Enzimol. 1997, $47,97-120$

15. Hasan, M.F. Controlling Anthracnose and Postharvest Quality of Papaya (Carica papaya cv. Frangi) Using Bacillus subtilis Strain B34. Ph.D. Thesis, Universiti Putra Malaysia, Selangor, Malaysia, 2012.

16. Sariah, M. Potential of Bacillus spp. as a biocontrol agent for anthracnose fruit rot of chilli. Malays. Appl. Biol. 1994, 23, 53-60.

17. Chanchaichaovivat, A.; Ruenwongsa, P.; Panijpan, B. Screening and identification of yeast strains from fruits and vegetables: Potential for biological control of postharvest chilli anthracnose (Colletotrichum capsici). Biol. Control 2007, 42, 326-335. [CrossRef]

18. Zheng, M.; Shi, J.; Shi, J.; Wang, Q.; Li, Y. Antimicrobial effects of volatiles produced by two antagonistic Bacillus strains on the anthracnose pathogen in postharvest mangos. Biol. Control. 2013, 65, 200-206. [CrossRef]

19. Al Zaemey, A.B.; Magan, N.; Thompson, A.K. Studies on the effect of fruit-coating polymers and organic acids on growth of Colletotrichum musae in vitro and on postharvest control of anthracnose of bananas. Mycol. Res. 1993, 97, 1463-1468. [CrossRef]

20. Droby, S.; Wisniewski, M.E.; Cohen, L.; Weiss, B.; Touitou, D.; Eilam, Y. Influence of $\mathrm{CaCl}_{2}$ on Penicillium digitatum, grapefruit peel tissue, and biocontrol activity of Pichia guilliermondii. Phytopathology 1997, 87, 310-315. [CrossRef]

21. Rahman, M.A.; Kadir, J.; Mahmud, T.M.M.; Abdul-Rahman, R.; Begum, M.M. Screening of Antagonistic Bacteria for Biocontrol Activities on Colletotrichum gloeosporioides in Papaya. Asian J. Plant Sci. 2007, 6, 12-20. [CrossRef]

22. Edwards, K.; Johnstone, C.; Thompson, C. A simple and rapid method for the preparation of genomic plant DNA for PCR analysis. Nucleic Acids Res. 1991, 19, 1349. [CrossRef]

23. White, T.J.; Bruns, T.; Lee, S.; Taylor, J. Amplification and direct sequencing of fungal ribosomal RNA genes for phylogenetics. In PCR Protocols: A Guide to Methods and Applications; Innis, M.A., Gelfand, D.H., Snisky, J.J., White, T.J., Eds.; Academic Press: San Diego, CA, USA, 1990. 
24. Hata, E.M.; Sijam, K.; Ahmad, Z.A.M.; Yusof, M.T.; Azman, N.A. In vitro Antimicrobial Assay of Actinomycetes in Rice against Xanthomonas oryzae pv oryzicola and as Potential Plant Growth Promoter. Braz. Arch. Biol. Technol. 2015, 58, 821-832. [CrossRef]

25. Nghia, N.A.; Kadir, J.; Sunderasan, E.; Abdullah, M.P.; Malik, A.; Napis, S. Morphological and Inter Simple Sequence Repeat (ISSR) Markers Analyses of Corynespora cassiicola Isolates from Rubber Plantations in Malaysia. Mycopathologia 2008, 166, 189-201. [CrossRef]

26. Shahnazi, S. Biological Characterization and Genetic Diversity of Fusarium spp. Associated with Yellowing Disease in Black Pepper (Piper nigrum L.) in Malaysia. Ph.D. Thesis, Universiti Putra Malaysia, Selangor, Malaysia, 2012.

27. Tamura, K.; Stecher, G.; Peterson, D.; Filipski, A.; Kumar, S. MEGA6: Molecular Evolutionary Genetics Analysis Version 6.0. Mol. Biol. Evol. 2013, 30, 2725-2729. [CrossRef]

28. Illeperuma, C.K.; Jayasuriya, P. Prolonged storage of 'Karuthacolomban' mango by modified atmosphere packaging at low temperature. J. Hortic. Sci. Biotech. 2002, 77, 153-157. [CrossRef]

29. Singh, V.; Deverall, B.J. Bacillus subtilis as a control agent against fungal pathogens of citrus fruit. Trans. Br. Mycol. Soc. 1984, 83, 487-490. [CrossRef]

30. Venkatachalam, K.; Meenune, M. Changes in physiochemical quality and browning related enzyme activity of longkong fruit during four different weeks of on-tree maturation. Food Chem. 2012, 131, 1437-1442. [CrossRef]

31. Tian, S.P.; Xu, Y.; Jiang, A.L.; Gong, Q.Q. Physiological and quality responses of longan fruit to high $\mathrm{O}_{2}$ or high $\mathrm{CO}_{2}$ atmospheres in storage. Postharvest Biol. Technol. 2002, 24, 335-340. [CrossRef]

32. Kokkinakis, D.M.; Brooks, J.L. Tomato peroxidases: Purification, characterization and catalytic properties. Plant Physiol. 1979, 63, 93-99. [CrossRef] [PubMed]

33. Jiang, Y.M.; Joyce, D.C. ABA effects on ethylene production, PAL activity, anthocyanin and phenolic contents of strawberry fruit. Plant Growth Regul. 2003, 39, 171-174. [CrossRef]

34. Wang, Y.S.; Tian, S.P.; Xu, Y.; Qin, G.Z.; Yao, H. Changes in the activities of pro- and anti-oxidant enzymes in peach fruit inoculated with Cryptococcus laurentii or Penicillium expansum at 0 or $20^{\circ} \mathrm{C}$. Postharvest Biol. Technol. 2004, 34, 21-28. [CrossRef]

35. Beers, J.R.F.; Sizer, I.W. A spectrophotometric method for measuring the breakdown of hydrogen peroxide by catalase. J. Biol. Chem. 1952, 95, 133-140. [CrossRef]

36. Kurabachew, H.; Wydra, K. Characterization of plant growth promoting rhizobacteria and their potential as bioprotectant against tomato bacterial wilt caused by Ralstonia solanacearum. Biol. Control 2013, 67, 75-83. [CrossRef]

37. Matića, S.; Spadaroa, D.; Garibaldia, A.; Gullinoa, M.L. Antagonistic yeasts and thermotherapy as seed treatments to control Fusarium fujikuroi on rice. Biol. Control 2014, 73, 59-67. [CrossRef]

38. Kurtzman, C.P.; Fell, J.W. The Yeasts: Taxonomic Study; Elsevier Science: Amsterdam, The Netherlands, 1998.

39. Druvefors, U. Yeast Biocontrol of Grain Spoilage Mold. Ph.D. Thesis, Swedish University of Agricultural Sciences, Uppsala, Sweden, 2004.

40. Janisiewicz, W.J.; Tworkoski, T.J.; Kurtzman, C.P. Biocontrol potential of Metchnikowia pulcherrima strains against blue mold of apple. Phytopathology 2001, 91, 1098-1108. [CrossRef] [PubMed]

41. Kurtzman, C.P.; Droby, S. Metschnikowia fructicola, a new ascosporic yeast with potential for biocontrol of postharvest fruit rots. Syst. Appl. Microbiol. 2001, 24, 395-399. [CrossRef]

42. Zheng, X.D.; Zhang, H.Y.; Sun, P. Biological control of postharvest green mold decay of oranges by Rhodotorula glutinis. Eur. Food Res. Technol. 2005, 220, 353-357. [CrossRef]

43. Pertot, I.; Giovannini, O.; Benanchi, M.; Caffi, T.; Rossi, V.; Mugnai, L. Combining biocontrol agents with different mechanisms of action in a strategy to control Botrytis cinerea on grapevine. Crop. Prot. 2017, 97, 85-93. [CrossRef]

44. Alvindia, D.G.; Natsuaki, K.T. Evaluation of fungal epiphytes isolated from banana fruit surfaces for biocontrol of banana crown rot disease. Crop. Prot. 2008, 27, 1200-1207. [CrossRef]

45. Li, L.; Ma, J.; Li, Y.; Wang, Z.; Gao, T.; Wang, Q. Screening and partial characterization of Bacillus with potential applications in biocontrol of cucumber Fusarium wilt. Crop. Prot. 2012, 35, 29-35. [CrossRef]

46. Narayanasamy, P. Biological Management of Diseases of Crops; Springer: New York, NY, USA, 2013.

47. Zhang, D.; Spadaro, D.; Garibaldi, A.; Gullino, M.L. Selection and evaluation of new antagonists for their efficacy against postharvest brown rot of peaches. Postharvest Biol. Technol. 2010, 55, 174-181. [CrossRef]

48. Sharma, N. Biological Controls for Preventing Food Deterioration; Wiley Blackwell: Chichester, UK, 2014.

49. Sharma, R.R.; Singh, D.; Singh, R. Biological control of postharvest diseases of fruits and vegetables by microbial antagonists: A review. Biol. Control 2009, 50, 205-221. [CrossRef]

50. Droby, S.; Chalutz, E.; Wilson, C.L. Antagonistic microorganisms as biocontrol agents of postharvest diseases of fruit and vegetables. Postharvest News Inf. 1991, 2, 169-173.

51. Janisiewicz, W.J. Biocontrol of postharvest diseases of temperate fruits: Challenges and opportunities. In Plant-Microbe Interactions and Biological Control; Boland, J., Kuykendall, L.D., Eds.; Marcel Dekker: New York, NY, USA, 1998.

52. El Ghaouth, A.; Wilson, C.L.; Wisniewski, M.E. Biologically-based alternatives to synthetic fungicides for the postharvest diseases of fruit and vegetables. In Diseases of Fruit and Vegetables; Naqvi, S.A.M.H., Ed.; Springer: Dordrecht, The Netherlands, 2004.

53. Zhang, D.; Spadaro, D.; Garibaldi, A.; Gullino, M.L. Potential biocontrol activity of a strain of Pichia guilliermondii against grey mold of apples and its possible modes of action. Biol. Control 2011, 57, 193-201. [CrossRef]

54. Selitrennikoff, C.P. Antifungal proteins. Appl. Environ. Microbiol. 2001, 67, 2883-2894. [CrossRef] [PubMed] 
55. Schmitt, M.J.; Breinig, F. Yeast viral killer toxins: Lethality and self-protection. Nat. Rev. Microbiol. 2006, 4, 212-221. [CrossRef]

56. Coelho, A.R.; Celli, M.G.; Ono, E.Y.S.; Wosiacki, G. Penicillium expansum versus antagonist yeasts with perspectives of application in biocontrol and patulin degradation. Braz. Arch. Biol. Technol. 2007, 50, 725-733. [CrossRef]

57. Hashem, M.; Alamri, S. The biocontrol of postharvest disease (Botryodiplodia theobromae) of guava (Psidium guajava L.) by the application of yeast strains. Postharvest Biol. Technol. 2009, 53, 123-130. [CrossRef]

58. Muccilli, S.; Wemhoff, S.; Restuccia, C.; Meinhardt, F. Exoglucanase-encoding genes from three Wickerhamomyces anomalus killer strains isolated from olive brine. Yeast 2013, 30, 33-43. [CrossRef]

59. Marquina, D.; Santos, A.; Peinado, J.M. Biology of killer yeasts. Int. Microbiol. 2002, 5, 65-71. [CrossRef] [PubMed]

60. Santos, A.; san Mauro, M.; Bravo, E.; Marquina, D. PMKT2, a new killer toxin from Pichia membranifaciens, and its promising biotechnological properties for control of the spoilage yeast Brettanomyces bruxellensis. Microbiology 2009, 155, 624-634. [CrossRef]

61. Breinig, F.; Tipper, D.J.; Schmitt, M.J. Kre1p, the plasma membrane receptor for the yeast K1 viral toxin. Cell 2002, 108, 395-405. [CrossRef]

62. Oregel-Zamudio, E.; Angoa-Pérez, M.V.; Oyoque-Salcedo, G.; Aguilar-González, C.N.; Mena-Violante, H.G. Effect of candelilla wax edible coatings combined with biocontrol bacteria on strawberry quality during the shelf-life. Sci. Hortic. 2017, 214, 273-279. [CrossRef]

63. Wisniewski, M.; Wilson, C.; Hershberger, W. Characterization of inhibition of Rhizopus stolonifer germination and growth by Enterobacter cloacae. Can. J. Bot. 1989, 67, 2317-2323. [CrossRef]

64. Arras, G.; de-Cicco, V.; Arru, S.; Lima, G. Biocontrol by yeasts of blue mold of citrus fruits and the mode of action of an isolate of Pichia guilliermondii. J. Hortic. Sci. 1998, 73, 413-418. [CrossRef]

65. Droby, S.; Chalutz, E.; Wilson, C.L.; Wisniewski, M.E. Characterization of the biocontrol activity of Debaryomyces hansenii in the control of Penicillium digitatum on grapefruit. Can. J. Microbiol. 1989, 35, 794-800. [CrossRef]

66. Droby, S.; Cohen, L.; Daus, A.; Weiss, B.; Horev, B.; Chalutz, E.; Katz, H.; Keren-Tzur, M.; Shachnai, A. Commercial testing of aspire: A yeast preparation for the biological control of postharvest decay of citrus. Biol. Control 1998, 12, 97-101. [CrossRef]

67. Wisniewski, M.; Biles, C.; Droby, S.; McLaughlin, R.; Wilson, C.; Chalutz, E. Mode of action of the postharvest biocontrol yeast, Pichia guilliermondii. I. Characterization of attachment to Botrytis cinerea. Physiol. Mol. Plant Pathol. 1991, 39, 245-258. [CrossRef]

68. El Ghaouth, A.; Wilson, C.; Wisniewski, M.; Droby, S.; Smilanick, J.L.; Korsten, L. Biological control of postharvest diseases of fruits and vegetables. Appl. Mycol. Biotechnol. 2002, 2, 219-238. [CrossRef]

69. Walsh, T.J.; Melcher, G.P.; Lee, J.W.; Pizzo, P.A. Infections due to Trichosporon species: New concepts in mycology, pathogenesis, diagnosis and treatment. Curr. Top. Med. Mycol. 1993, 5, 79-113.

70. Arnaldo, L.C.; Padovan, A.C.B.; Chaves, G.M. Current Knowledge of Trichosporon spp. and Trichosporonosis. Clin. Microbiol. Rev. 2011, 24, 682-700. [CrossRef] 